\title{
Triangular law of students' Mathematics Interest in Ghana: A Model with motivation and perception as predictor
}

\author{
Samuel Asiedu -Addo ${ }^{a}$, Charles K. Assuah ${ }^{\mathrm{a}}$ and Yarhands Dissou Arthur ${ }^{\mathrm{b}}$ \\ aDepartment of Mathematics Education, Faculty of Science Education, University of \\ Education, Winneba Campus. Ghana. \\ ${ }^{b}$ Department of Interdisciplinary Studies, College of Technology Education, University of \\ Education, Kumasi Campus, day1981boy@yahoo.com. P.O. Box 1277 Kumasi, Ghana
}

\begin{abstract}
The main purpose of this study was to verify by means of structural equation modelling (SEM) how students' interest in mathematics (SIM) is affected by students' perception and students' motivation to learn mathematics. The study further investigated the effect of students' perception (SP) on students' motivation (SM) to learn mathematics. The study adopted a simple random sampling technique to administer 150 questionnaires to 10 public Senior High Schools in Ghana. In all, a total number of 1,500 students were given the questionnaire to indicate their responses. However, 1,263 questionnaires were properly administered, representing $84.3 \%$ response rate. The constructs reliability for SIM, SP, and SM were $0.71,0.82$, and 0.68 respectively. The further explored how the goodness-of-fit influences the measurement model, structural model and the overall model. The findings indicated that when Ghanaian high school students' have good perception about mathematics and have the motivation to learn mathematics, their interest in mathematics would improve significantly.
\end{abstract}

KEYWORDS

Students' perception; students' motivation; students' interest; Ghana; Mathematics
ARTICLE HISTORY

Received 11 September 2016 Revised 23 November 2016 Accepted 14 February 2017

\section{Introduction}

The perception of students about Mathematics and their students' motivation to learn Mathematics is of great importance to students' interest in mathematics (Arthur, Asiedu-Addo, \& Assuah, 2017; Martin, 2006; Meece, Wigfield, \& Eccles, 1990). Students' interest in mathematics is key in their

\section{CORRESPONDENCE Yarhands Dissou Arthur day1981boy@yahoo.com}

(c) 2017 Samuel Asiedu -Addo, Charles K. Assuah \& Yarhands Dissou Arthur.

Open Access terms of the Creative Commons Attribution 4.0 International License apply. The license permits unrestricted use, distribution, and reproduction in any medium, on the condition that users give exact credit to the original author(s) and the source, provide a link to the Creative Commons license, and indicate if they made any changes. (http://creativecommons.org/licenses/by/4.0/) 
performance and achievement. Achievement and performance have as a result been the subject of investigation for mathematics educators, researchers and other stakeholders (Bong, 2004; Skaalvik \& Skaalvik, 2008). The mathematics interest construct has received very little attention in stakeholders' quest to finding solution to poor performance of mathematics among students across the globe, especially in Africa (Linnenbrink-Garcia et al., 2010).

The attention on achievements and performance should be linked to interest constructs since performance and achievement are driven by interest. Predictors of students achievements and performance such as attitude, selfconcept, self-efficacy among other has received some level of attentions its deserves but these same variables relations with the students interest has received little attention (Githua \& Mwangi, 2003). The study by (Pantziara \& Philippou, 2007) revealed a higher correlation between self-efficacy and fear of failure. Furthermore, a higher correlation between fear of failure and interest was also found by the previous study. This further implied that the importance of interest in the achievement process of students in mathematics is very important and requires further investigation for further update of literature. Students' attitude towards mathematics significantly have effect on their outcomes in the subject (Köğce, Yildiz, Aydin, \& Altindağ, 2009). Despite the importance of the subject, mathematics is usually perceived as a boring, cold, difficult, not practical and as abstract by students (Ignacio, Nieto, \& Barona, 2006). These negative perceptions held by students, if not reversed could impact negatively on their interest and subsequently performance. Students' negative attitude they demonstrate in their academic life has been linked to their lack of motivation and achievement (Mensah, Okyere, \& Kuranchie, 2013; Singh, Granville, \& Dika, 2002a). Students' attitudes relating to attendance to school and classes, participation and preparedness for mathematics classes (for instance coming to school late, skipping classes, coming to unprepared without books and home works), have been linked with student motivation and achievement (Singh, Granville, \& Dika, 2002b). The present study claims that interest in mathematics produces some level of confidence for students' achievement in mathematics. Similar to this assertion is the study by (Tooke \& Lindstrom, 1998), on the role of confidence in students achievement in mathematics which confirmed that confidence in learning and problem solving is important in student achievement. The importance of students' interest in mathematics cuts across all levels of education. Students in higher classes, Class 14 , demonstrate very high interest in mathematics and high self-efficacy beliefs. Furthermore, students in Class 11 have a very high fear of failure. Students in the lower classes, Class 3, show high performance goals (Pantziara \& Philippou, 2007). Mathematics is regarded as an important technical and natural science subject by engineering and science students. However, students do not have high convictions of the application of mathematics in their field of studies (Matic, 2014). The lack of interest in mathematics may be due to lack of application in the daily activities and work places although mathematics is the very basis for technological and industrial development in the world. This study seeks to fill the gap by contributing to mathematics education literature on contribution of students' perception and students' motivation on students' interest in mathematics. The study could contribute to the limited literature on the students' interest in mathematics by expanding the scope of literature. The study conceptualises that, students interest in mathematics is affected by 
students perception and students motivation. The study further conceptualises that students' motivation to learn mathematics is influenced by their perception about mathematics.

\section{Research Objectives}

i. To determine the extent to which students' perception influences students' interest in mathematics

ii. To examine the impact of students' motivation on students' interest in mathematics

iii. To investigate the extent to which students' perception about mathematics affect students' interest in mathematics.

\section{Research Questions}

i. To what extent does students' perception about mathematics significantly affect students' interest in Mathematics?

ii. To what does students' perception about mathematics influence students' motivation to learn mathematics?

iii. Does students' motivation to learn mathematics significantly affect their interest in mathematics?

\section{Research Hypotheses}

i. H1: Students' perception about mathematics significantly affects students' interest in mathematics.

ii. H2: Students' motivation about mathematics significantly influences students' interest in mathematics.

iii. H3: Students' perception about mathematics significantly affects students' motivation to learn mathematics.

\section{Research Methods}

The present study adopted methodology relevant to contemporary research for the realization of underpinning research objectives questions and hypothesis.

\section{Study Design and Approach}

The study used sample survey method for data collection needed for investigating the problem understudy. The present study used purely quantitative research paradigm to generate the needed statistics and results. The exploratory and explanatory design was used since the study sought to explore the influence of students' motivation and students' perception on students' interest in mathematics. The study however included explanatory for the purpose of explaining the extent of effect students perception and student motivation exert on students interest in mathematics.

The study first explores the reliability of the instrument and further used it to explain the effect of the construct on student interest in Mathematics 
The study used self-constructed questionnaire instrument for the purpose of geographical and cultural barriers of the Ghanaian students. The difficulties of Ghanaian students requires that factors peculiar to them deserves investigation for further integration to into bigger global picture. The study used the five point Likert scale to measure students interest in mathematics, students motivation and students perception in mathematics. Participants ranked measurement of students' interest, students' motivation and students' perception by strongly agreeing, agreeing neutral disagreeing or strongly disagreeing to measurement of students' interest, student motivation and students' perception construct.

\section{Population, Sample and Sampling Techniques}

The present study used random sampling techniques select participants to be included in the study. Two stage cluster sampling techniques was adopted to select participants from 10 senior high schools in the Ashanti region of Ghana. The various programmes were put into clusters since all students in all programmes cannot but studied. The first stage select programmes to be included in a participating school then a simple random sample of participants were then selected to participate in the study. On average 150 participants were randomly selected from the participating schools, however, 1,263 participants properly responded to the questionnaire instrument representing $84.2 \%$ response rate. For the purpose of data protection from the participating schools and students, ethical clearance was given by the faculty of science education graduate research review committee for commencement of data collection. Furthermore, the participants were made to participate freely and willingly with the assurance that all information and data obtained will be used for academic purpose with assured anonymity.

\section{Results and findings}

The study previously determined the reflective measurement model that need to be dropped based on unidimensionality or multidimensionality procedure that aimed at dropping the indicator or item with Cronbach's alpha value less than 0.6. The results indicated in Table 1, shows that after multidimensionality procedure, the construct indicators produced with composite reliability value $>0.7$, indicating the extent of internal consistency as well as construct reliability ( Hair, Sarstedt, \& Ringle, 2012; Henseler, Ringle, \& Sinkovics, 2009). The structural equation model analysis proceeded with item whose Cronbach's alpha values were more than 0.6 for further analysis to create feasible models for the student interest. The study performed composite reliability, convergent and discriminant validity test to ascertain the conformity of the constructs indicators measuring what it is meant to measure and not necessarily reflecting other constructs than the construct it intern to measure. The study presented the reliability statistics based on the PLS algorithm and bootstrapping techniques which provided the $t$-statistics. The standardised $\mathrm{t}$ statistics is useful in determining the hypothesis indicated in the structural model. The values of standardised t-statistics greater than 1.96 are basically assumed to be significant and otherwise are not statistically significant (Fornell \& Larcker, 1981). To determine the existence of discriminant validity, two statistics were employed namely the average variance extracted (AVE) and HTMT. The square root of the AVE was compared with correlations between the 
constructs and other constructs and was found to be greater than the correlations. This confirms discriminant validity however, form further confirmation of the discriminant validity the HTMT was used for further clarity and confirm further for the discriminant validity. The results from the study revealed that students motivation and students' perception significantly predicts students' interest in mathematics and explains $22.2 \%$ of variance in students' interest in mathematics. The results reveals further that, students' perception of mathematics can explain $26.1 \%$ of students motivation to study mathematics as indicated in Figure 1 and Figure 2.

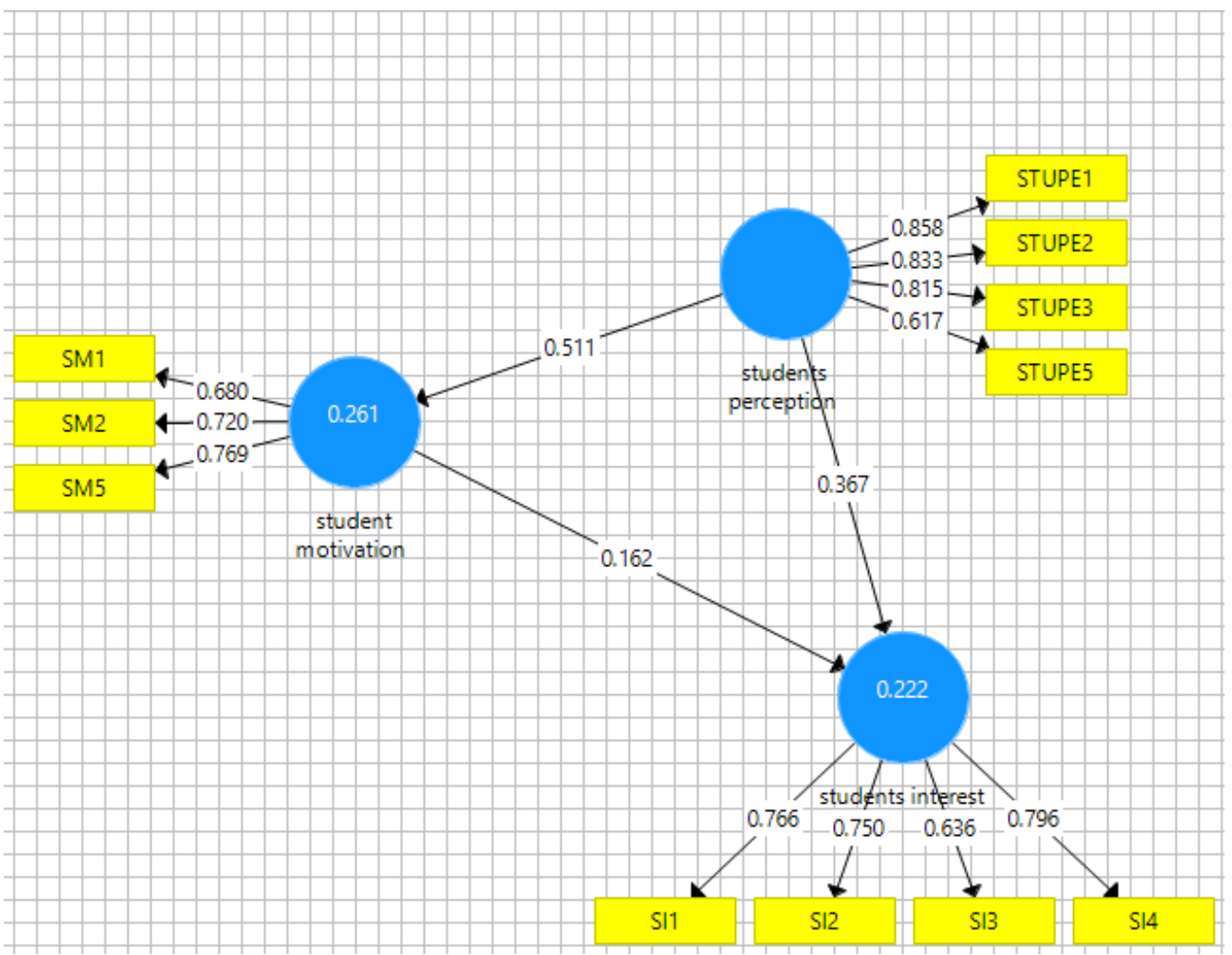

Figure 1 Empirical Triangular PLS -SEM algorithm 


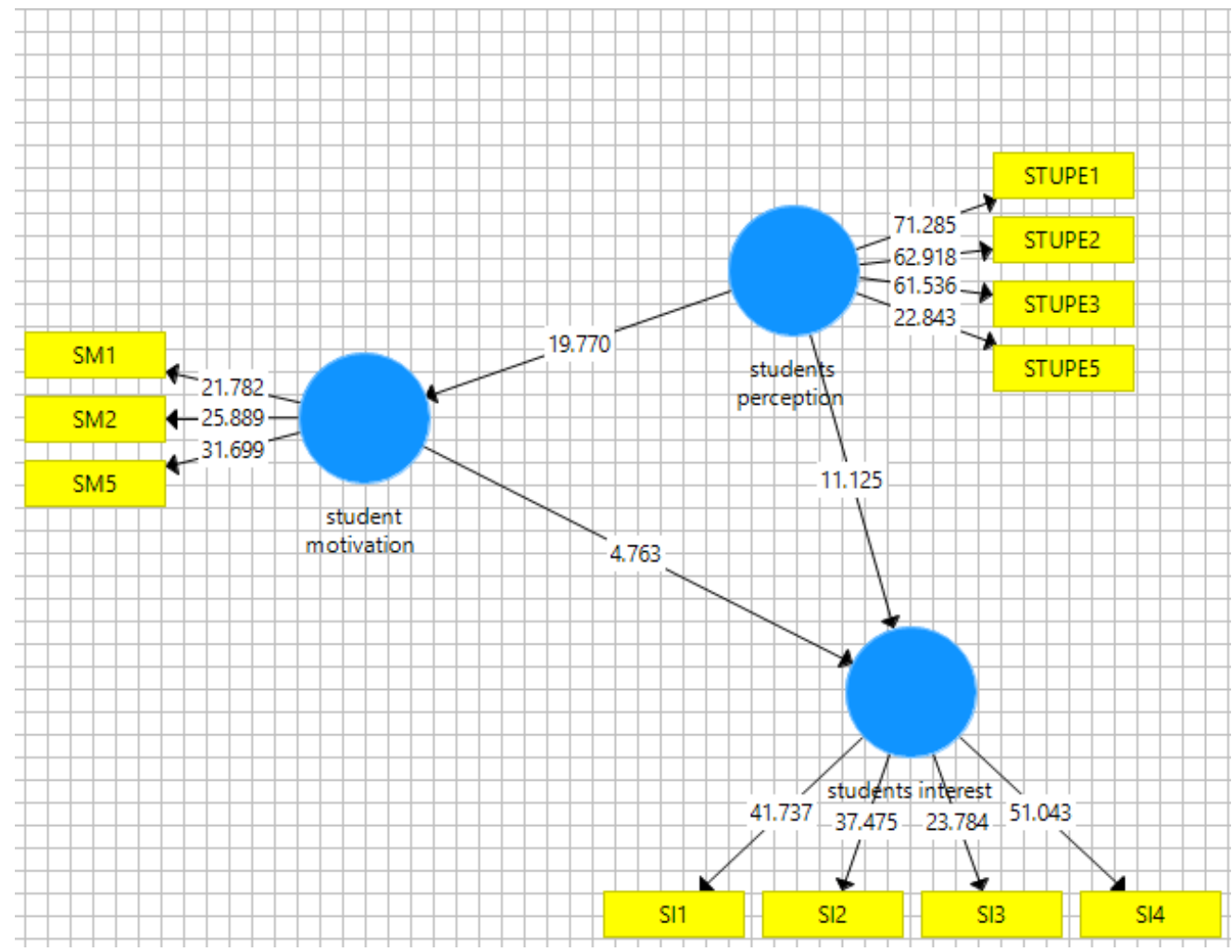

Figure 2 Empirical Triangular model of students' interest in Mathematics.

Table 1 Construct Reliability and Validity

\begin{tabular}{lllll}
\hline & Cronbach's Alpha & rho_A & Composite Reliability & $\begin{array}{l}\text { Average } \\
\text { Extracted (AVE) }\end{array}$ \\
Students' & 0.567 & 0.575 & 0.767 & 0.524 \\
Motivation & & & & \\
Students' Interest & 0.724 & 0.742 & 0.828 & 0.547 \\
Students & 0.789 & 0.811 & 0.865 & 0.619 \\
Perception & & & & \\
\hline
\end{tabular}

Table 2 Discriminant Validity Fornell-Larcker Criterion

\begin{tabular}{llll}
\hline & student motivation & students interest & students perception \\
Students' Motivation & 0.724 & & \\
Students' Interest & 0.350 & 0.740 & \\
Students Perception & 0.511 & 0.450 & 0.786 \\
\hline
\end{tabular}


Table 3 Model Fit Summary

\begin{tabular}{lll}
\hline & Saturated Model & Estimated Model \\
SRMR & 0.090 & 0.090 \\
d_ULS & 0.538 & 0.538 \\
d_G & 0.151 & 0.151 \\
Chi-Square & $1,081.556$ & $1,081.556$ \\
NFI & 0.722 & 0.722 \\
\hline
\end{tabular}

Table 4 Average Variance Extracted (AVE) Mean, STDEV, T-Values, P-Values

\begin{tabular}{llllll}
\hline Constructs & $\begin{array}{l}\text { Original } \\
\text { Sample } \\
(\mathbf{O})\end{array}$ & $\begin{array}{l}\text { Sample } \\
\text { Mean }(\mathbf{M})\end{array}$ & $\begin{array}{l}\text { Standard Deviation } \\
(\mathbf{S T D E V})\end{array}$ & $\begin{array}{l}\text { T Statistics } \\
(\mathbf{O} / \mathbf{S T D E V})\end{array}$ & P Values \\
$\begin{array}{l}\text { Student } \\
\text { Motivation }\end{array}$ & 0.524 & 0.524 & 0.017 & 30.165 & 0.000 \\
$\begin{array}{l}\text { Students Interest } \\
\text { Students }\end{array}$ & 0.547 & 0.547 & 0.013 & 42.324 & 0.000 \\
Perception & 0.619 & 0.619 & 0.012 & 50.720 & 0.000 \\
\hline
\end{tabular}

Table 5 Heterotrait-Monotrait Ratio (HTMT) Mean, STDEV, T-Values, P-Values

\begin{tabular}{|c|c|c|c|c|c|c|}
\hline & & $\begin{array}{l}\text { Original } \\
\text { Sample } \\
\text { (O) }\end{array}$ & $\begin{array}{l}\text { Sample } \\
\text { Mean } \\
(\mathrm{M})\end{array}$ & $\begin{array}{l}\text { Standard } \\
\text { Deviation } \\
\text { (STDEV) }\end{array}$ & $\begin{array}{l}\text { T Statistics } \\
(|\mathrm{O} / \mathrm{STDEV}|)\end{array}$ & P Values \\
\hline students interest & -> student motivation & 0.519 & 0.521 & 0.045 & 11.465 & 0.000 \\
\hline students perception & -> student motivation & 0.723 & 0.724 & 0.040 & 18.041 & 0.000 \\
\hline students perception & -> students interest & 0.581 & 0.582 & 0.037 & 15.827 & 0.000 \\
\hline
\end{tabular}

Table 6 Composite Reliability Mean, STDEV, T-Values, P-Values

\begin{tabular}{|c|c|c|c|c|c|c|}
\hline Constructs & $\begin{array}{l}\text { Original } \\
\text { Sample (O) }\end{array}$ & $\begin{array}{l}\text { Sample Mean } \\
\text { (M) }\end{array}$ & $\begin{array}{l}\text { Standard } \\
\text { (STDEV) }\end{array}$ & Deviation & $\begin{array}{l}\mathrm{T} \quad \text { Statistics } \\
(|\mathrm{O} / \mathrm{STDEV}|)\end{array}$ & P Values \\
\hline student motivation & 0.767 & 0.766 & 0.013 & & 59.465 & 0.000 \\
\hline students interest & 0.828 & 0.827 & 0.008 & & 108.789 & 0.000 \\
\hline students perception & 0.865 & 0.865 & 0.006 & & 138.104 & 0.000 \\
\hline
\end{tabular}

\section{Discussion}

Influence of students perception on students interest in mathematics 
The hypothesis that students' interest in mathematics is influenced by the students' perception in mathematics was found to be significant. The findings suggested a direct relationship between students' interest in mathematics and student students perception $(0.367, \mathrm{p}<0.001)$. This suggests further that students exhibition of positive perception of mathematics will further improve their interest in mathematics. The more positive perception student hold about teaching and learning of mathematics will significantly improve their interest in mathematics (Mutodi \& Ngirande, 2014b). When students are given academic counselling to renew their perception about mathematics, they will improve their interest in mathematics and further impact on achievement and performance in mathematics. The results which consistent with the earlier studies in ( Arthur et al., 2017; Arthur, Oduro, \& Boadi, 2014) .

\section{Influence of students motivation on students' interest in mathematics}

The study tested the hypothesis that student interest in mathematics is influenced by student motivation. The study finding suggests that there exist a direct relationship between students interest in mathematics and students motivation to learn mathematics $(r=0.162, p<0.05)$. The study revealed a positive and statistical significant relationship between students interest and student motivation to learn mathematics. The results furthers suggest that the more students are motivated to learn mathematics the more interest students demonstrate in mathematics. This contributes to the literature of mathematics education and expand the scope of literature in that student will be interested in mathematics most of the time if student are motivated to learn mathematics. The educational leadership and stakeholders are required to institute measures that promote students motivation since it has direct relationship with the student interest to learn mathematics. consistent to this study is the finding from (Mutodi \& Ngirande, 2014a; Skaalvik \& Skaalvik, 2008).

\section{Influence of students perception on students motivation to learn mathematics}

The hypothesis that students' perception influences students' motivation to learn mathematics was test at 0.05 level of significance. The results indicated a direct relationship between students' perception about mathematics and the students' interest in mathematics $(r=0.511, p<0.001)$. The result of the study suggested that as students positively perceive mathematics, the more students are motivated to learn mathematics. Thus as students' positively perceive mathematics by erasing misconception about mathematics the more motivated students will be in the learning of mathematics. The results is also consistent with other findings in (Arthur et al., 2017; Mutodi \& Ngirande, 2014a).

\section{Conclusions and Recommendation}

The study modelled students' interest in mathematics based on perception and motivation of the students. The study determined the influence of students' perception and students' motivation on students' mathematics interest. The study concluded that, students' interest in mathematics is significantly and positively predicted by their perception and motivation about the mathematics. The study further concluded that student perception about mathematics further predicts their motivation to learn mathematics significantly. The study moreover concluded that student interest in mathematics could be improved if 
students' motivation for studying mathematics and the perception about mathematics improves. The more students are motivated positively to learn mathematics with renewed perception, the more interested the students would demonstrate in mathematics. The study recommended for stakeholder and mathematics educator to invest activities that will positively improve student perception in mathematics and further motivate them both intrinsic and extrinsic. The study recommended for stakeholders and mathematics educators to engage students in activities that will influence their motivation for learning mathematics. The use of technology in teaching and learning of mathematics should be encouraged at the early stages of the children education to help eradicate the negative perception students have for mathematics.

\section{Disclosure statement}

No potential conflict of interest was reported by the authors.

\section{Notes on contributors}

Samuel Asiedu -Addo is a lecturer at the Department of Mathematics Education, Faculty of Science Education, University of Education, Winneba Campus. Ghana.

Charles K. Assuah is a lecturer at the aDepartment of Mathematics Education, Faculty of Science Education, University of Education, Winneba Campus. Ghana

Yarhands Dissou Arthur, is a lecturer at the Department of Interdisciplinary Studies, College of Technology Education, University of Education, Kumasi Campus, Kumasi, Ghana

\section{References}

Arthur, Y., Asiedu-Addo, S., \& Assuah, C. (2017). Students' Perception and Its Impact on Ghanaian Students' Interest in Mathematics: Multivariate Statistical Analytical Approach. Asian Research Journal of Mathematics, 4(2), 1-12. http://doi.org/10.9734/ARJOM/2017/33023

Arthur, Y. D., Oduro, F. T., \& Boadi, R. K. (2014). Statistical Analysis of Ghanaian Students Attitude and Interest Towards Learning Mathematics . International Journal of Education and Research, 2(6), 661-670.

Bong, M. (2004). Academic Motivation in Self-Efficacy, Task Value, Achievement Goal Orientations, and Attributional Beliefs. The Journal of Educational Research, 97(6), 287-298. http://doi.org/10.3200/JOER.97.6.287-298

Fornell, C., \& Larcker, D. (1981). Evaluating structural equation models with unobservable variables and measurement error. Journal of Marketing Research, 18(3), 39-50. http://doi.org/10.2307/3151312

Githua, B. N., \& Mwangi, J. G. (2003). Students' mathematics self-concept and motivation to learn mathematics : relationship and gender differences among Kenya's secondary-school students in Nairobi and Rift Valley provinces. International Journal of Educational Development 23, 23, 487-499. http://doi.org/10.1016/S0738-0593(03)00025-7

Hair, J. F., Black, B., Babin, B., TathamR.L, \& R.E, A. (2005). Multivariate Data analysis. Singapore: Peason Education (Pte).

Hair, J., Sarstedt, M., \& Ringle, C. (2012). An assessment of the use of partial least squares structural equation modeling in marketing research. Journal of the Academy of Marketing Science, 40(3), 414-433.

Henseler, J., Ringle, C., \& Sinkovics, R. (2009). The use of partial least squares path modeling in international marketing. Advances in International Marketing, 20, 277-319.

Ignacio, N., Nieto, L., \& Barona, E. (2006). The affective domain in mathematics learning. Retrieved from http://citeseerx.ist.psu.edu/viewdoc/summary?doi=10.1.1.495.3040 
Köğce, D., Yildiz, C., Aydin, M., \& Altindağ, R. (2009). Examining elementary school students' attitudes towards mathematics in terms of some variables. Procedia - Social and Behavioral Sciences, 1(1), 291-295. http://doi.org/10.1016/j.sbspro.2009.01.053

Linnenbrink-Garcia, L., Durik, A. M., Conley, A. M., Barron, K. E., Tauer, J. M., Karabenick, S. A., \& Harackiewicz, J. M. (2010). Measuring Situational Interest in Academic Domains. Educational and Psychological Measurement, 70(4), 647-671. http://doi.org/10.1177/0013164409355699

Martin, A. J. (2006). The relationship between teachers' perceptions of student motivation and engagement and teachers' enjoyment of and confidence in teaching. Asia-Pacific Journal of Teacher Education, 34(1), 73-93. http://doi.org/10.1080/13598660500480100

Matic, L. J. (2014). Mathematical knowledge of non-mathematics students and their beliefs about mathematics. International Electronic Journal of Mathematics Education, 9(1-2), 13-24.

Meece, J. L., Wigfield, A., \& Eccles, J. S. (1990). Predictors of math anxiety and its influence on young adolescents' course enrollment intentions and performance in mathematics. Journal of Educational Psychology, 82(1), 60-70. http://doi.org/10.1037/0022-0663.82.1.60

Mensah, J. K., Okyere, M., \& Kuranchie, A. (2013). Student attitude towards Mathematics and performance: Does the teacher attitude matter? Journal of Education and Practice, 4(3), 132139.

Mutodi, P., \& Ngirande, H. (2014a). Exploring Mathematics Anxiety: Mathematics Students' Experiences. Mediterranean Journal of Social Sciences, 5(1). http://doi.org/10.5901/mjss.2014.v5n1p283

Mutodi, P., \& Ngirande, H. (2014b). The Influence of Students 'Perceptions on Mathematics Performance . A Case of a Selected High School in South Africa. Mediterranean Journal of Social Sciences, 5(3), 431-445. http://doi.org/10.5901/mjss.2014.v5n3p431

Pantziara, M., \& Philippou, G. (2007). Students ' motivation and achievement and teachers ' practices in the classroom, Proceedings of 31th PME Conference 4, 57-64.

Singh, K., Granville, M., \& Dika, S. (2002a). Mathematics and science achievement: effects of motivation, interest, and academic engagement. The Journal of Educational Research, 95(6), 323-332. http://doi.org/10.1080/00220670209596607

Singh, K., Granville, M., \& Dika, S. (2002b). Mathematics and Science Achievement: Effects of Motivation, Interest, and Academic Engagement. The Journal of Educational Research, 95(6), 323-332. http://doi.org/10.1080/00220670209596607

Skaalvik, E. M., \& Skaalvik, S. (2008). Self-concept and self-efficacy in mathematics: Relation with mathematics motivation and achievement. New Developments in the Psychology of Motivation., $105-128$.

Tooke, D. J., \& Lindstrom, L. C. (1998). Effectiveness of mathematics methods course in reducing math anxiety of preserves elementary teacher. School Science \& Mathematics, 98(3), 136-139. 